Portland State University

PDXScholar

6-2-1993

\title{
Cultural Bias in the Assessment of Phonological Processes in Conjunction with the APP-R
}

Sharon Elise Soliday

Portland State University

Follow this and additional works at: https://pdxscholar.library.pdx.edu/open_access_etds

Part of the Speech and Rhetorical Studies Commons

Let us know how access to this document benefits you.

\section{Recommended Citation}

Soliday, Sharon Elise, "Cultural Bias in the Assessment of Phonological Processes in Conjunction with the APP-R" (1993). Dissertations and Theses. Paper 4671.

https://doi.org/10.15760/etd.6554

This Thesis is brought to you for free and open access. It has been accepted for inclusion in Dissertations and Theses by an authorized administrator of PDXScholar. Please contact us if we can make this document more accessible: pdxscholar@pdx.edu. 
AN ABSTRACT OF THE THESIS OF Sharon Elise Soliday for the Master of Science in Speech Communication: Speech and Hearing Sciences presented June 2, 1993.

Title: Cultural Bias in the Assessment of Phonological Processes in Conjunction with the APP-R

APPROVED BY THE MEMBERS OF THE THESIS COMMITTEE:
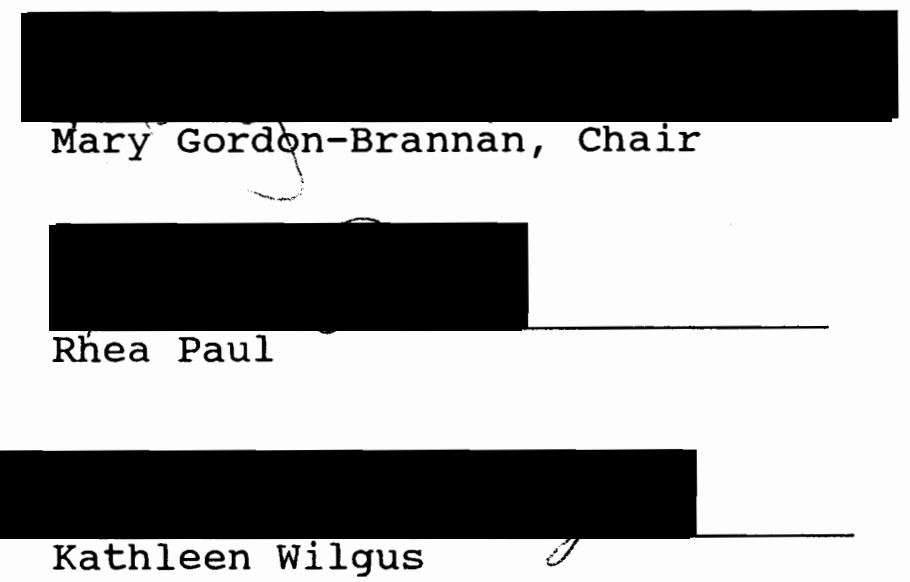

Normal phonological development is characterized by phonological processes in preschool children. These processes are sound error patterns, in relation to the adult target, that are expected within the speech of normally developing children. As children grow older, they "outgrow" these developmental errors.

Within the black English dialect, speakers may use a combination of these processes and not be consiciered 
phonologically impaired within their Iinguistic community.

The purpose of this study was to assess and compare phonological process usage in the speech of lower socioeconomic black and white preschoolers.

The APP-R in conjunction with the CAPP was administered to two groups of 15 children to determine if significant differences exist in the usage of phonological processes between the two groups. Group 1 was comprised of 15 black preschoolers from an inner-city preschool program. Group 2 was comprised of 15 white preschoolers from a Headstart program. All children were identified by their respective speech-language pathologist as having normally developing speech for their linguistic community.

Data analysis revealed black preschoolers used phonological processes with a higher frequency than white preschoolers. The phonological process usage mean for the black preschoolers was $4.26 \%(S D=1.94)$ and the mean for the white preschoolers was $1.71 \%(S D=2.86)$. Three of the ten basic processes were determined to be significantly different between the two groups, including: consonant. sequence omission, strident deviation, and velar deviation. The results were further examined to determine if either group of preschoolers was identified as needing phonological remediation based on their performance on the APP-R. None of the subjects in either group was identified as needing phonological remediation. 
In conclusion, results indicated black English speaking preschoolers did use significantly more phonological processes in their speech, however, the APP-R did not identify these children as needing phonological remediation. These results demonstrate the $A P P-R$ to be an appropriate assessment tool when evaluating the speech of this Portland black English speaking sample. 
CULTURAL BIAS IN THE ASSESSMENT OF PHONOLOGICAL PROCESSES

IN CONJUNCTION WITH THE APP-R

by

SHARON ELISE SOLIDAY

A thesis submitted in partial fulfillment of the requirements for the degree of

\author{
MASTER OF SCIENCE \\ in \\ SPEECH COMMUNICATION: \\ SPEECH AND HEARING SCIENCE
}

Portland State University

1993 
TO THE OFFICE OF GRADUATE STUDIES:

The members of the Committee approve the dissertation of Sharon Elise Soliday presented June 2, 1993.

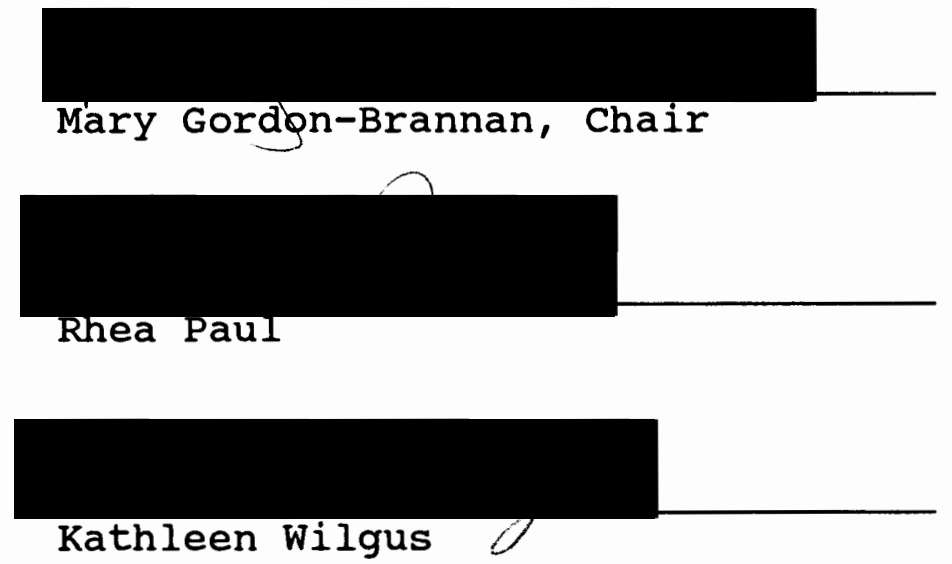

APPROVED :

Stepheh A. Kosokoff, Chair, Department of Speech Communication

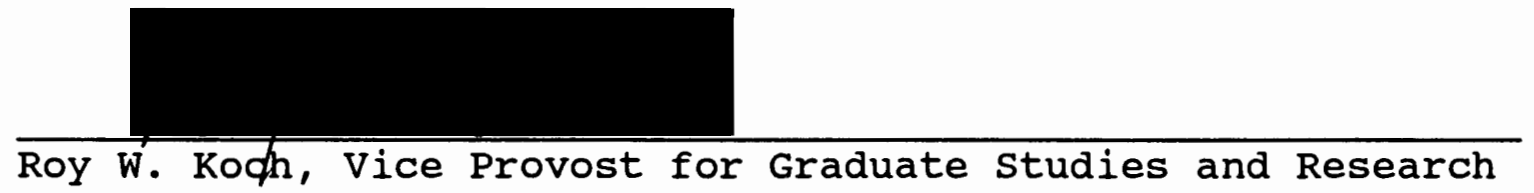




\section{ACKNOWLEDGEMENTS}

I want extend my greatest appreciation to my advisor, Mary Gordon-Brannan, for her constant support and direction. Her weekly meetings and availability to listen to my Concerns allowed me to finish this project on time.

I also want to thank the staff and administration of Humboldt Elementary of Portland Public Schools and North Beaverton Headstart for their willingness and cooperation in allowing me to come into their programs to assess students. A special thank you to Stephanie Herrick who provided direction and fast answers to possible on-site problems.

As a graduate peer, I want to thank Britteny Davis for listening to numerous tapes and entering data, in order to establish reliability. As a friend, I want to thank her for her ability to always find the positive side to whatever research problem I was confronted with.

I want to thank Franklin Bender for his love and support and understanding when sometimes I needed to disappear for days at a time.

I want to thank my mother for sharing her research knowledge, strategy techniques, and her never-ending "of course, you'll make it" attitude. 
TABLE OF CONTENTS

PAGE

ACKNOWLEDGEMENTS . . . . . . . . . . . . . . . . . iii

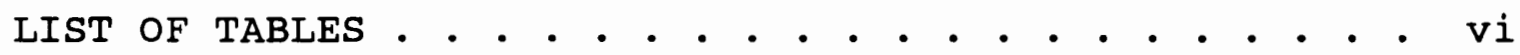
LIST OF FIGURES. . . . • . . . . . . . . . . . . . . vii CHAPTER

I INTRODUCTION AND STATEMENT OF PURPOSE. . . . . . 1 Introduction . . . . . . . . . . . 1 Statement of Purpose. . . . . . . . 3 Definition of Terms . . . . . . . . 4 II REVIEW OF THE LITERATURE • . . . . . . . . . 6 Traditional Speech Sound Analysis . . . 6 Normal Acquisition Data Assessment Remediation

Phonological Processes. . . . . . . . 10 Normative Phonological Data Assessment Remediation

Phonological Processes of Black English • .19 Consonant sequence Reduction Post-Vocalic Singleton Omission Stridency Deviation

III METHODS. . . . . . . . . . . . . . . . .22 General Plan of Study . . . . . . . . . 22 Subjects. . . . . . . . . . . . . . . 22 


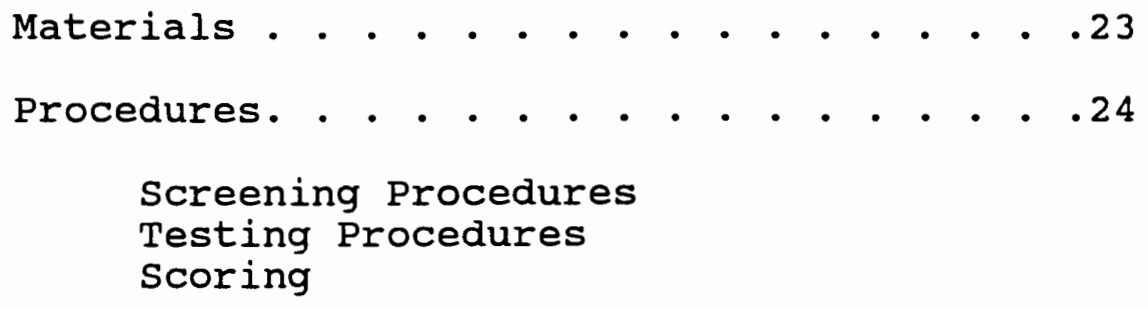

Data Analysis... . . . . . . . . 26

IV RESULTS AND DISCUSSION . . . . . . . . . . .29

Results . . . . . . . . . . . . . 29

Discussion. . . . . . . . . . . . .31

$\mathrm{V}$ SUMMARY AND IMPLICATIONS . . . . . . . . . . 37

Summary . . . . . . . . . . . . . . . .

Implications. . . . . . . . . . . 38

Research

Clinical

REFERENCES . . . . . . . . . . . . . . . . .42 APENDICES

A CONSENT FORM FOR SUBJECTS PARENTAL CONSENT • . .46

B SLP CHECKLIST FOR SUBJECT NORMAL SPEECH DEVELOPMENT . . . . . . . . . . . . .49

C COMMUNICATION SCREEN PROTOCOL. . . . . . . .51

D THE ASSESSMENT OF PHONOLOGICAL PROCESSESREVISED. . . . . . . . . . . . . . . .53 


\section{LIST OF TABLES}

I Age Levels For Phonemes Development According to Seven Studies . . . . . . . . . . . . 9

II The Frequency of Occurrence of Phonological Process Errors by Age (Haelsig \& Madison, 1986).17

III APP-R Average Percentage of Phonological Processes. Mean Scores of Percentage of Phonological Usage, Standard Deviations, and $t$-Values for the Black Preschool Group and the White Preschool Groups . . . . . . . 30

IV Means, Standard Deviation, and $\underline{t}$-Values for the APP-R ten Phonological Processes For Each Group of Subjects . . . . . . . . . . .32 


\section{LIST OF FIGURES}

FIGURE

PAGE

1. Chronology of Phonological Processes . . . . 16

2. Chi-Square Representing White and Black Preschoolers Identified as Phonologically Impaired . . . . . . . . . . . . . . . .27 
CHAPTER I

INTRODUCTION AND STATEMENT OF PURPOSE

INTRODUCTION

In the field of speech-language pathology, normative data are used for determining which individuals are classified as speech disordered or delayed. Determining eligibility for speech and/or language services is necessary in order to determine who will receive professional speech-language intervention. However, when normative data are established using only a specific group of people (e.g., race, sex, age, geographical region, and socioeconomic level), it would be expected that these data should be used only for the demographic group from which they were gathered.

For example, it would be inappropriate to apply normative developmental data established for a southern Texas dialect to an individual living in the Northwest. Unfortunately, normative data are often applied to demographic groups different from the norming group, although such a procedure may not be appropriate.

When individuals are expected to perform at a standard established with a group different from their own demographic profile, they may inaccurately be labeled 
speech-language disordered or delayed. Professional ethics and public law (P.L. 94-142) require that speech-language evaluations be conducted with non-discriminatory testing of students who are potentially disabled (Neidecker, 1987). Speech-language pathologists are not adhering to those guidelines when specific normative data are applied to individuals outside of that demographic group on which the test is normed.

Phonological processes describe the sound systems by which children acquire phonemes. Although normative sequences of phonological acquisition have been established, all children may not utilize phonological processes at the same rate or in the same way. For the most part, current normative data for phonological process acquisition are based upon standard English-speaking (predominately white middle-class) preschoolers (Dyson \& Paden, 1983; Hodson \& Paden, 1991; Ingram, 1989; Khan, Dyson, Edwards, Hodson, \& Preisser, 1985; Preisser, Hodson, \& Paden, 1988; StoelGammon \& Dunn, 1985). It cannot be assumed that children with different cultural characteristics would perform as children in these norming samples do. Currently, the performance of clients from differing cultural backgrounds is often compared to the mainstream norming sample, resulting in possibly inaccurate labeling of such clients as speech disordered or delayed, which is a violation of public law 94-142. ASHA (1990) has concluded that speech 
differences stemming from cultural variation do not indicate a speech or language deviation that warrants remediation. In order to distinguish between speech-language disorder and cultural variation, it is necessary to compare data collected from a specific cultural group (race, sex, age, geographical region, and/or socioeconomic level) with mainstream normative data to determine if significant discrepancies exist.

\section{STATEMENT OF PURPOSE}

The purpose of this study is to investigate possible cultural bias in the standards of the APP-R for analyzing use of phonological processes by lower socioeconomic African-American preschool children. Two groups of preschoolers were examined: (a) lower SES white and (b) lower SES black. The white preschoolers were expected to perform within the current "normal" range when assessed by the Assessment of Phonological Processes-Revised (APP-R) (Hodson, 1986) in conjunction with Computer Analysis of Phonological Processes (CAPP) (Hodson, 1985).

The first research hypothesis tested was that when the average of phonological deviations (calculated by the CAPD) of the two study groups are compared, there are differences between the performance of lower SES white preschoolers and lower SES black preschoolers. The second research hypothesis was that lower SES black preschoolers are 
identified as needing phonological remediation, whereas, lower SES white preschoolers are not identified for phonological remediation. If the lower SES black preschool group appeared disordered or delayed, such results suggest that the APP-R does not discriminate cultural variation from a specific speech deviation in lower SES black preschoolers.

The corresponding null hypotheses were:

1. There is no difference between the average phonological deviation scores obtained by lower SES black preschoolers and lower SES white preschoolers. Neither study group are identified as needing phonological remediation.

Subjects were determined normally developing based upon two standards. The black preschoolers were judged by the school SLP as normally developing. The white preschoolers were formally assessed with standardized measures by the SLP on site.

\section{DEFINITION OF TERMS}

This study will examine the following 11 phonological processes as described within the APP-R (Hodson, 1986):

Backing: moving the place of articulation to a more posterior position. For example, /bot/ $\rightarrow /$ bok $/$.

Consonant sequence reduction: omission of one or more consonants in a consonant sequence or cluster. For example, /stap/ $\rightarrow / t a p /$. 
Glide deviation: a glide phoneme is omitted or substituted by a non-glide phoneme; the glides are /w/ and $/ j /$. For example, $/ j \varepsilon l o / \rightarrow / \varepsilon 10 /$.

Liquid/1/ deviation: a liquid / / is omitted or substituted by another phoneme. For example, $/ 1\lrcorner \mathrm{k} / \rightarrow / \mathrm{j} \rho \mathrm{k} /$.

Liquid / $/$ / deviation: a Iiquid / $r /$ is omitted or substituted by another phoneme. For example, $/ r \wedge n / \rightarrow / w \wedge n /$.

Nasal deviation: a nasal phoneme is omitted or substituted by a non-nasal phoneme; the nasals are $/ \mathrm{m} /, \mathrm{n} /$, and $/ z /$. For example, /nel $1 \rightarrow / d e 1 /$.

Postvocalic singleton omission: omission of a singleton consonant that ends a syllable. For example, $/ \mathrm{k} \wedge$ $\mathrm{p} / \rightarrow / \mathrm{kn} /$.

Prevocalic singleton omission: omission of a singleton consonant that initiates a syllable. For example, /k $\wedge$ p $\rightarrow$ $/ \wedge \mathrm{p} /)$

stridency deviation: strident sound is omitted or is substituted by a nonstrident phoneme; the stridents are /s/, $/ z /, / S /, / \zeta /, / f /, / \mathrm{v} /, / \theta /$, and $/ \lambda /$. For example, /s $\wedge$ $m / \rightarrow / t \wedge m /$.

Syllable reduction: the omission of an entire syllable in the target word. For example, /pra b bl $I / \rightarrow / p r a b l I /$. Velar deviation: a velar sound is omitted or substituted by a non-velar sound; velar sounds are $/ \mathrm{k} /, / \mathrm{g} /$, and $/ z /$. For example, $/ k \supset t / \rightarrow / t \partial t /$. 
CHAPTER II

\section{REVIEW OF THE LITERATURE}

This chapter describes traditional and phonological approaches for examining sound acquisition and phonological development. The types of normative data, assessment procedures, and intervention procedures used by these approaches will be reviewed. Phonological patterns typically used by black English speakers are also briefly addressed.

\section{TRADITIONAL SPEECH SOUND ANALYSIS}

In the traditional sound-by-sound approach, target sounds for intervention are generally selected based on sound acquisition normative data. This type of data specify the age levels when individual sounds are produced correctly as compared to adult models.

\section{Normal Acquisition Data}

Normative data have been established for 24 consonant phonemes, but differences between initial and subsequent studies make comparison difficult (Smit, 1986). Although the goal of determining the age of acquisition of individual speech sounds is the same, criteria and methods used by various researchers have differed, leading to differing 
results as to the age of acquisition. For example, researchers have used various methods to answer questions, such as at what point is a sound considered "acquired" by a child and what stimuli are provided to the child to elicit the desired sounds?

In 1972, sander compared three earlier studies, two of which required a $90 \%$ correct criterion before the sound was considered to be acquired and one which required only a $51 \%$ criterion $151 \%$ of the children produce the sound correctly in at least two word positions). The results indicated a large discrepancy between what is considered normal acquisition dependent on the criterion used.

In addition, smit (1986) noted differences with consistency between prior studies when she examined how stimuli were presented by the various researchers. Some of the investigators recorded the sound production during spontaneous connected speech; others presented a model to be imitated; still others used non-imitated single-word productions. Each of these methods influenced how the sound was produced and at what age it was considered to be acquired.

With her associates, Smit (1990) completed the most recently published study to assess the age of phoneme acquisition. The study examined children between the ages of 3:0 and 9:0. Preschoolers were recruited from public and private preschools and school-age children were recruited 
from public grammar schools. All children spoke standard Midwestern dialect. The assessment instrument used one-word photographic stimuli. From results of their study, the investigators concluded that the criteria used to determine acceptability of a production influenced outcomes for some speech sounds. These researchers plotted curves of individual acquisition and then, utilizing a $90 \%$ criteria, determined a general level of acquisition. Table I compares sound acquisition data produced by 7 studies, illustrating inconsistencies as to when the 24 English consonants are considered to be acquired.

\section{Assessment}

As traditional normative data examine acquisition of consonant sounds individually, assessment for articulation errors also examine individual sounds. Numerous assessment tools are available to test sound acquisition in individuals in a traditional method. For example, the Goldman-Fristoe Test of Articulation (Goldman \& Fristoe, 1969), the Photo Articulation Test (Pendergast, Dickey, Selmar, \& Sodar, 1965), the Arizona Articulation Proficiency Scale (Fudala \& Reynolds, 1961), the Developmental Articulation Test (Hejna, 1963), and the Templin-Darley Test of Articulation (Templin \& Darley, 1969) are traditional tests that elicit one-word, non-imitative responses with each word targeting one or two sounds in the initial, medial, and/or final positions. The Deep Test of Articulation (McDonald, 1964) is another 


\begin{tabular}{|c|c|c|c|c|c|c|c|}
\hline \multirow[b]{3}{*}{ Sound } & \multicolumn{7}{|c|}{ TABLE I } \\
\hline & \multicolumn{7}{|c|}{$\begin{array}{l}\text { AGE LEVELS FOR PHONEME DEVELOPMENT } \\
\text { ACCORDING TO SEVEN STUDIES }\end{array}$} \\
\hline & $\begin{array}{l}\text { Wellman } \\
1931\end{array}$ & $\begin{array}{l}\text { Poole } \\
1934 \\
\end{array}$ & $\begin{array}{c}\text { Templin } \\
1957 \\
\end{array}$ & $\begin{array}{l}\text { Sander } \\
1972\end{array}$ & $\begin{array}{l}\text { Prather } \\
1975 \\
\end{array}$ & $\begin{array}{l}\text { Arlt \& Goodban } \\
1976 \\
\end{array}$ & $\begin{array}{l}\text { Smit et al. } \\
1990\end{array}$ \\
\hline $\mathrm{m}$ & 3 & 3.6 & 3 & before 2 & 2 & 3 & 3 \\
\hline $\mathrm{n}$ & 3 & 4.6 & 3 & before 2 & 2 & 3 & $3-3.6$ \\
\hline $\mathrm{h}$ & 3 & 3.6 & 3 & before 2 & 2 & 3 & 3 \\
\hline $\mathrm{p}$ & 4 & 3.6 & 3 & before 2 & 2 & 3 & 3 \\
\hline f & 3 & 5.6 & 3 & 3 & $2-4$ & 3 & $3.6-5$ \\
\hline w & 3 & 3.6 & 3 & before 2 & $2-8$ & 3 & 3 \\
\hline b & 3 & 3.6 & 4 & before 2 & $2-8$ & 3 & 3 \\
\hline 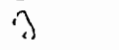 & & 4.6 & 3 & 2 & 2 & 3 & $7-9$ \\
\hline j & 4 & 4.6 & 3.6 & 3 & $2-4$ & & 45.6 \\
\hline k & 4 & 4.6 & 4 & 2 & $2-4$ & 3 & 3.6 \\
\hline $\mathrm{g}$ & 4 & 4.6 & 4 & 2 & $2-4$ & 3 & $3.6-4$ \\
\hline$i$ & 4 & 6.6 & 6 & 3 & $3-4$ & 4 & $5-7$ \\
\hline $\mathrm{d}$ & 5 & 4.6 & 4 & 2 & $2-4$ & 3 & $3-3.6$ \\
\hline $\mathrm{t}$ & 5 & 4.6 & 6 & 2 & $2-8$ & 3 & $3.6-4$ \\
\hline$s$ & 5 & 7.6 & 4.6 & 3 & 3 & 4 & $7-9$ \\
\hline$r$ & 5 & 7.6 & 4 & 3 & $3-4$ & 5 & 8 \\
\hline$+S$ & 5 & & 4.6 & 4 & $3-8$ & 4 & $6-7$ \\
\hline$v$ & 5 & 6.6 & 6 & 4 & 4 & 3.6 & 5.6 \\
\hline$z$ & 5 & 7.6 & 7 & 4 & 4 & 4 & $7-99$ \\
\hline 3 & 6 & 6.6 & 7 & 6 & 4 & 4 & \\
\hline$\theta$ & & 7.6 & 6 & 5 & 4 & 5 & $6-8$ \\
\hline$d=3$ & & & 7 & 4 & 4 & 4 & $6-7$ \\
\hline$S$ & & 6.6 & 4.6 & 4 & $3-8$ & 4.6 & $6-7$ \\
\hline$\lambda$ & & 6.6 & 7 & 5 & 4 & 5 & $4.6-7$ \\
\hline
\end{tabular}

Adapted from Creaghead, Newman, \& Secord, 1989, modified by Gordon-Brannan, 1992 
traditional test, but uses a different format in that it tests each individual consonant in approximately 60 contexts in order to examine their co-articulatory effects on each other at a two-word level.

In these traditional tests, individual target sounds are broadly transcribed if they are misarticulated, denoting omissions, substitutions, distortions, and additions. Although sounds may be duplicated within a test, they are often only targeted once for transcription (except for the Deep Test of Articulation) which does not account for articulation inconsistencies.

\section{Remediation}

Traditional remediation approaches target sounds individually. A speech-language clinician may choose to target more than one sound for remediation at any given time. Targeting individual phonemes typically involves a sequence of contexts. The clinician first teaches the sound in isolation, progressing through nonsense syllables, single words, and short phrases. The final context would be spontaneous, connected speech. Approximations of a target sound are not accepted within treatment after the client has successfully articulated the target sound.

\section{PHONOLOGICAL PROCESSES}

The theory of phonological process usage evolved from the inconsistencies of speech sound production by children 
as they are developing their speech. Although researchers (Arlt \& Goodban, 1976; Poole, 1934; Prather, Hendrick, \& Kern, 1975; Sander, 1972; Smit, Hand, Freilinger, Bernthal, \& Bird, 1990; Templin, 1957; Wellman, Case, Mengert, \& Bradbury, 1931) disagree as to the age at which sounds are acquired, they do agree as to the general order of development of speech sounds (Table I). Weiss, Gordon, and Lillywhite (1987) and Ferguson and Farwell (1975) noted that acquisition of phonemes is a slow process with particular sounds at one time being produced correctly, only later to be produced incorrectly by the same child. This supposed regression in speech sound acquisition is developmentally appropriate for children who are learning to articulate the adult standard phonemes. These researchers noted phonological patterns are influenced and may change depending upon the word contexts in which they occur and variations exist across lexical items. A word may be said correctly initially, but change over time as the child learns other phonemic patterns.

\section{Normative Phonological Data}

Phonological processes are rules that describe a child's production in relation to the adult target. Many of these processes are developmental in nature, that is, normally developing children use phonological processes in their speech. Hodson and Paden (1991) explained that children cannot "immediately learn the entire array of 
phonemes or the complicated set of sequence patterns of the language they will eventually use" (p. 5). With this in mind, phonological processes occur most often when children simplify complex phonological patterns with phonemes that are already within their repertoire. Generally, children are considered phonologically impaired when they do not outgrow these developmental phonological deviations or when they have acquired and maintained phonological patterns that are not developmental in nature. For example, backing is not developmental in nature.

The acquisition of phonological patterns varies from child to child (Weiss et al., 1987). However, some "phonological landmarks" can be specified as follows:

(1) vowel-consonant discrimination is acquired first; (2) stop-continuant discrimination is acquired early; (3) the development of stops and nasals precedes the development of fricatives, affricates, and semi-vowels; (4) labial sound development precedes dental, alveolar, and velar sound development, in that order; (5) place of articulation precedes acquiring of voicing features; (6) high and low features of vowel development precede acquisition of front-back features; (7) single consonants precede consonant clusters in development; (8) consonants are acquired first in the initial position of words; and (9) syllabic patterns develop as follows: CV, CVC, and CVCV where C represents consonants and V represents vowels (Ervin-Tripp, 1966 in Weiss et al., 1987, p. 76).

Ingram (1989) divided phonologic processes into three categories: syllable structure, assimilation, and substitution. Sound changes for either substitution or assimilation may be relative to manner, place, or voicing of 
phoneme production. Syllable structure processes change the composition of syllables in words. This study will

investigate the syllable structure processes of final consonant deletion (e.g., /k / for cup), cluster reduction (e.g., /tJ p/ for stop), and weak syllable deletion (e.g., /prablI/ for probably) each of which is considered a normally developing process.

Assimilation, sometimes referred to as harmony, occurs when a sound or syllable of a word is changed to become more like another sound or syllable of the given word. Two types of assimilation are described, that is, progressive and regressive assimilation. Progressive assimilation occurs when a sound is changed based upon the sound that precedes it (e.g.,/dつd/ for dog). Regressive assimilation occurs when a sound is changed due to the sound that follows it (e.g., $/ \mathrm{g} \mathrm{Jg} /$ for dog). Both types of changes are considered normally developing phonological processes. Substitution is identified by stoel-Gammon and Dunn (1985) as one sound being replaced by another without being influenced by surrounding phonemes. Substitutions are generally one class of phonemes (liquids, stops, fricatives, affricates, nasals, and/or glides) being replaced by another class of phonemes. Examples of some of these class substitutions appear at the end of chapter one. Sound changes for either substitution or assimilation may be relative to manner, place, or voicing of phoneme production. 
It has already been stated that individual children utilize different processes. Some researchers (Edwards \& Shriberg, 1983) specified strategies that children may be utilizing to explain the differences among their process usage. The first strategy is selection or avoidance in which children may choose to avoid sounds that are too difficult for them to articulate. Children may substitute or omit completely these difficult sounds. The second strategy is avoidance of homonyms in which children do not use words which sound the same within their current phonologic system. Some homonyms may be avoided, but others may not be, depending upon the child's comfort level. Limited output patterns is another strategy and occurs when a child uses one type of structural pattern to form various words. For example, a child may use a monosyllabic, cVC pattern. Another strategy used is absolute position constraints in which a child chooses certain sounds that are used exclusively in a certain word or syllable position. The process of assimilation described earlier is also considered a strategy. Finally, another strategy is unique reduction devices in which a child chooses to use a particular vowel or $C V$ to represent the syllable of a word (Edwards \& Shriberg, 1983).

These strategies and process usage normally occur within children prior to the age of 3 years with a gradual reduction of processes witnessed until the age of 5 years, 
although some processes continue after the age of 5 . Table II represents the frequency of occurrence of phonological process errors in children ages 3-5 years, at 6-month intervals (Haelsig \& Madison, 1986). Figure 1 represents the chronology of phonological processes (Grunwell, 1987). More recently, Preisser, Hodson, and Paden (1988) examined developmental phonology of children under 3 years of age, but only included subjects from middle-class SES homes with monolingual English speaking families. Within the discussion of that research, the investigators stated that phonological data also need to be collected from "various cultures, communities, and socioeconomic levels" (p. 128).

\section{Assessment}

Like traditional testing of speech sounds, phonology may be examined through an elicited or spontaneous sample with words, phrases, or connected speech as the speech output. However, unlike traditional testing, phonology is examined by observing the patterns of sound production rather than individual sounds.

Several tests exist to assess child phonological processes. One of the first persons to develop a system for phonological process analysis was Ingram (1981). This system examines the child's phonetic inventory for sounds in all positions and the frequency of syllable types. One of the first types of analysis developed to examine phonological processes was the Natural Process Analysis 


\begin{tabular}{|c|c|c|c|c|c|c|c|}
\hline & $2.0-2: 6$ & $2: 6-3: 0$ & $3: 0-3.6$ & $3: 6-4: 0$ & $4: 0-4.6$ & $4.6-5.0$ & $5.0-$ \\
\hline \multicolumn{8}{|l|}{$\begin{array}{l}\text { Weak syilable } \\
\text { deletion }\end{array}$} \\
\hline \multicolumn{8}{|l|}{$\begin{array}{l}\text { Final consonant } \\
\text { deletton }\end{array}$} \\
\hline \multicolumn{8}{|l|}{ Reduplication } \\
\hline \multicolumn{8}{|l|}{$\begin{array}{l}\text { Consonant } \\
\text { harmony }\end{array}$} \\
\hline \multicolumn{8}{|l|}{$\begin{array}{l}\text { Cluster reduction } \\
\text { (initial) } \\
\text { obstruent + } \\
\text { approximant } \\
|s|+\text { consonant }\end{array}$} \\
\hline \multicolumn{8}{|l|}{ Stopping } \\
\hline 181 & & & & \multicolumn{2}{|c|}{$101-[d]$ or $[v]$} & & \\
\hline$|s|$ & & ---- & & & & & \\
\hline III & & Fronting & s| type' & & & & \\
\hline$\left|19 . d_{3}\right|$ & & & Fronting fts. & 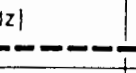 & $--\infty$ & - & \\
\hline Fronting $/ x, g, n /$ & & ---- & $=-$ & & & & \\
\hline Griaing $|r| \rightarrow[w]$ & & & ----- & $-\cdots-1$ & --- & --- & --- \\
\hline $\begin{array}{l}\text { Context-sensitive } \\
\text { voicing }\end{array}$ & & & & & & & \\
\hline
\end{tabular}

Figure 1. Chronology of phonological processess (Grunwell, 1987. 
TABLE II

THE FREQUENCY OF OCCURRENCE OF PHONOLOGICAL PROCESSES

BY AGE (HAELSIG \& MADISON, 1986)

Age Levels

PHONOLOGICAL

PROCESS

Gliding liquids

Weak syllable deletion

Glottal replacement

Cluster Reduction

Labial assimilation

Vocalizations

Stopping

Fronting

Alveolar assimilation

Final devoicing

Denasalization

Velar assimilation

Gliding of fricatives

Affrication

Deletions of final consonants
3:0

3:6

4:0

55

37

31

18

14

40

21

9

25

0

8

2

8

5

15

8

24

27

8

10

14

26

8

6

8

1

0

0

0

0

0

22

6

28

13

$8-6$

15

7

4

2

$6 \quad 1$

6

0

$\begin{array}{ll}0 & 1\end{array}$

2

2

$0 \quad 0$

$0 \quad 10$

$0 \quad 0$

2

2

0

0

10

5 
created by Shriberg and Kwiatkowski (1980). His analysis examines eight processes through a spontaneous language sampling procedure. The Phonological Process Analysis (Weiner, 1979) elicits single words and phrases with a delayed model in reference to pictures. Eighteen processes in three classifications (syllable structure, harmony, and feature contrast or substitution) are examined.

The most recent tests developed include the APP-R which can be analyzed through the Hodson Computer Analysis of Phonological Processes (CAPP) (Hodson, 1985) or CAPD, and the Khan-Lewis Phonological Analysis (KLPA) (Khan \& Lewis, 1986). The KLPA examines the child's productions for 12 normally developing and 3 not normally developing phonological processes. Both the APP-R and KLPA use elicited, single-word productions. The child's production of the entire word is phonemically transcribed and analyzed for phonological processes. The APP-R, the test utilized for this research, examines the following 11 phonological processes, 10 of which are considered normally developing: backing (not developmental), consonant sequence reduction, glide deviation, liquid /l/ deviation, liquid /r/ deviation, nasal deviation, prevocalic singleton omission, postvocalic singleton omission, stridency deviation, syllable reduction, and velar deviation. Each process is defined with examples at the end of chapter one. It should be explained that the $A P P-R$ and CAPD recommend targeting a phonological process 
for intervention when it occurs in $40 \%$ or more in the possible contexts (Hodson, 1986, 1992).

\section{Remediation}

Unlike traditional remediation in which the clinician targets individual sounds in one or more positions based upon developmental expectations, phonological remediation focuses on targeting patterns that either are not developmental in nature or have been retained by the child for too long a period of time.

\section{PHONOLOGICAL PROCESSES OF BLACK ENGLISH}

Black English is a linguistic code utilized primarily by working class African Americans in the United States (Shames \& Wiig, 1986). Some of the phonological patterns typically used by these speakers may be identified as deviant phonological processes on the APP-R. Although this assessment tool may identify these processes as deviant, the linguistic standard within the black English speaking community is the use of these phonological processes in everyday speech.

It should be noted that there is no common denominator of what phonological processes constitute "black English." Rather, process usage that is considered normal is determined by the community of speakers and region of the country where the speakers live. Phonological patterns of black English in relation to the processes examined by the 
APP-R will now be reviewed. It should not be expected that black English speakers necessarily use all of these phonological changes all the time within their speech.

\section{Consonant sequence Reduction}

Black English speakers may reduce consonant blends to single consonants (Adler, 1979; Hixon, Shriberg, \& Saxman, 1980). For example, the test word star may be changed within the rules of black English to be produced as /sar/ or /tar/ and still be phonologically correct within that linguistic community. Within the APP-R, the test word boats may be verbalized as /bot/; omitting the final consonant /s/. This, however, may actually reflect a morphological pattern of omitting the plural (Dale, 1976) that the APP-R interprets as a consonant sequence reduction. Omitting the possessive marker is also a characteristic of black English. It should be noted that the APP-R does not include any items which are possessive. Glide, Liquid /1/, Liquid /r/, and Nasal Deviations. Within the $A P P-R, / 1 /$ and $/ r /$ may be omitted by black English speakers in the medial and final position of target test words (Seymour \& Seymour, 1981) and target nasal sounds may be substituted among each other (Adler, 1979; Hixon et al., 1980). These changes would not be appropriate within a standard English speaking community; however, within the black English dialect, these patterns may be the phonological standard. 
Post-Vocalic singleton omission

Black English speakers may utilize post-vocalic singleton omissions, the deletion of a consonant sound at the end of a syllable or word (Hixon et al., 1980;

Smitherman, 1977). For example, within the APP-R, a Black English speaker may say /b a skI/ for /bæskIt/.

\section{Stridency Deviation}

Black English speakers may omit or use a substitution for fricative sounds (/s, z, $\left.\int, z, f, v /\right)$ (Hixon et al., 1980; Smitherman, 1977). Within the APP-R, for example, the initial / / / sound in shoe may be substituted by a sound such as $/ \mathrm{s} /$.

These phonological differences are dialectical in nature and speakers should be judged in comparison with the standards of their own linguistic community. Unfortunately, normative data for phonological processes are generally established utilizing only the limited linguistic community of white, middle-class preschoolers. These data are expected to penalize the normally developing black English speaker. 
CHAPTER III

\section{METHODS \\ GENERAL PLAN OF STUDY}

This study was designed to investigate phonological process usage of preschool children from different cultural backgrounds. The scores of two groups of preschool children on a phonological instrument were compared with each other and again with normative data. One group was comprised of white, lower SES children and the other group was AfricanAmerican, lower SES children.

\section{SUBJECTS}

The subjects comprised two groups of 15 children each. The mean age for each group was 5:3, with a range from 4:6 to 5:6. Group A was comprised of white, lower socioeconomic preschoolers with a mean age of 5:3. Group B was comprised of black, lower socioeconomic preschoolers with a mean age of 5:3. All participants were from two preschool programs in the Portland, Oregon metropolitan area. All subjects met the following criteria:

1. had signed parental permission to participate (Appendix A) 
2. passed a pure-tone hearing screening at $25 \mathrm{~dB}$ for the frequencies of $500,1000,2000$, and $4000 \mathrm{~Hz}$

3. had normally developing speech, in relation to their own linguistic community, as reported by the speech-language pathologists (Appendix B).

To screen receptive and expressive language skills of the black preschool group the communication Screen (Striffler, N., \& Willig, S., 1981) was administered (Appendix C). Program directors at the white preschool did not want their preschoolers to be subjected to additional screening. The speech-language pathologist (SLP) had completed a developmental screening of language skills two months prior to this research being completed. The SLP's records verified that all subjects within this test group had appropriate language skills.

\section{MATERIALS}

A portable Qualitone audiometer, model AS-110, was used to conduct the hearing screening on the day of testing. The APP-R in conjunction with the CAPP (Appendix D) was used to determine which phonological processes are used by the subjects. A Calrad unidirectional microphone 10-14A in conjunction with a Panasonic portable cassette recorder RQ-2102 was utilized to tape-record each subject's responses to the administration of the APP-R. 
PROCEDURES

\section{Screening Procedures}

Hearing was screened on the day of phonological assessment for the black preschool group. The SLP for the white preschool group confirmed test subjects had passed a hearing screening as a part of the site's developmental screen 2 months prior. The speech-language pathologist for each designated site confirmed students had normally developing speech in relation to their linguistic community by completing the form provided by this primary investigator (Appendix B). The testing room was on-site at each preschool program.

\section{Testing Procedures}

The APP-R was administered by this investigator. All subjects were presented with five bags of stimulus items, placed on the floor with the white preschoolers and on a table with the black preschoolers, each bag was presented individually. When the subject picked up an object, the clinician asked, "What is that?" The subject's response was then transcribed on-line. If the subject did not initiate the task of picking up an object, the clinician began the task by picking up one of the objects and then asking, "What is this?" If the subject did not respond or responded incorrectly, the correct answer was provided and the question was repeated by the examiner (a delayed model). If 
the subject continued to hesitate or did not respond with the target answer, the examiner said "(Subject's name), say (target word)" (a direct model). If either of these models are used to elicit the appropriate response, it was noted on the score sheet with a checkmark $(\checkmark)$ indicating a delayed model and/or a star (A) indicating a direct model. All 50 test items were presented in this manner until the test was completed, approximately 15-30 minutes for each subject was needed. Administration of the test was tape recorded.

\section{Scoring}

When subjects had been tested, transcribed results were scored with the CAPP. When all 50 items had been input into the computer, the program ran an analysis for 11 possible phonological processes to assess the subject's performance. The software then determined whether deviations were sufficient to label the child as phonologically deviant and the severity level of the deviancy. To ensure reliability of transcribed results, two measures were taken. The first was to have a graduate student in speech-language pathology independently transcribe all stimuli responses from each subject from the audiotaped test administration. Transcriptions were compared with investigators' on-line transcriptions. There was a $90 \%$ agreement between the investigator and independent transcriber. Discrepancies occurred 14 times during comparison of the researcher's and the graduate student's transcription. The transcription by 
the graduate student blind to group identification was utilized for analysis.

Secondly, to ensure accuracy of input into the CAPP, each child's test results were entered twice. Discrepancies between the two entries were noted and input errors were corrected.

\section{DATA ANALYSIS}

To analyze the data and determine if differences existed between the phonological process usage of lower SES white preschoolers and lower SES black preschoolers, three sets of analysis were completed. To test the first hypothesis, the average of phonological deviations are different for the two groups, a t-test of independent means was used to compare the averages of the percentage of phonological deviations for the two groups.

of the 11 phonological processes examined by the APP-R and CAPP, percentage of occurrence for some individual phonological processes were higher in usage in one group than in the other group. Differences were examined with post-hoc t-tests for independent means.

To test the second hypothesis, a chi-square $\left(x_{2}\right)$ (Figure 2) was expected to be used to compare the percentage of children who were identified as phonologically impaired. It was expected lower SES black preschoolers would be identified as needing phonological remediation, whereas, 
White Preschoolers Black Preschoolers

Phonologically

impaired

Not identified as phonologically

impaired

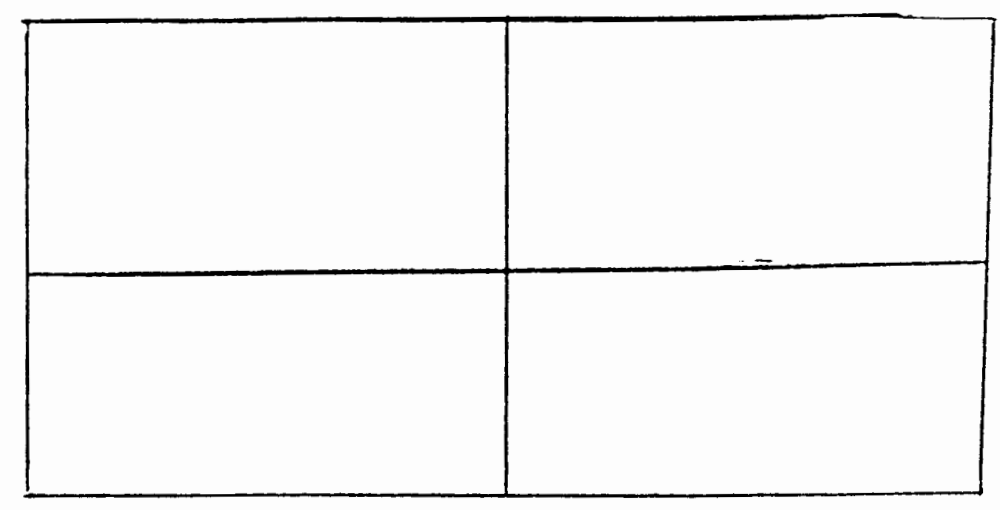

Figure 2. Chi-Square representing white and black preschoolers indentified as phonologically

impaired. 
lower SES white preschoolers would not be identified for phonological remediation. 


\section{CHAPTER IV \\ RESULTS AND DISCUSSION}

\section{RESULTS}

This study investigated possible cultural bias within the APP-R by assessing normally developing, lower socioeconomic white and black preschoolers. Each group of preschoolers was administered the APP-R with performance results computed by the CAPD.

In order to address the first research question, the means of the percentage of phonological deviations of the groups were compared. A two-tailed $t$-test for independent means was applied to determine if a difference between the two groups exists. The resulting $t$ of $2.82(\mathrm{df}=28)$ showed statistically significant differences beyond the .01 level of confidence (Table III) with the black preschool subjects using a higher percentage of occurrence of phonological processes $(\bar{x}=4.26 \% ; S D=1.94)$ than the white preschoolers $(\bar{x}=1.71 \% ; S D=2.86)$.

To determine which phonological processes were significantly different, $t$-tests for independent means were computed on the ten basic phonological processes tested by the APP-R. Of the ten processes, three were statistically significant beyond the .01 level, including consonant 
TABLE III

APP-R AVERAGE PERCENTAGE OF PHONOLOGICAL PROCESSES

MEAN SCORES OF PERCENTAGE OF PHONOLOGICAL USAGE, STANDARD

DEVIATIONS, AND $t$-VALUES FOR THE BLACK PRESCHOOL GROUP AND THE WHITE PRESCHOOL GROUP

Group

Mean

SD

df t-Value

Black Preschoolers $\quad 4.26$

1.94

$28 \quad 2.82$

White Preschoolers $\quad 1.71 \quad 2.86$ 
sequence omissions, strident deficiency, and velar deficiency. The black preschoolers used the three processes more frequently than did the white subjects. The percentage of usage of the other seven processes, including syllable reduction, pre- and post-vocalic singleton omission, liquid /I/ deviation, liquid / $/$ deviation, nasal deviation, and glides, were not statistically significantly different. Backing was not used by any of the subjects. Table IV displays the means, standard deviations, and $t$-values for the phonological processes for each group of subjects. The second research question examined the number of white verses black preschoolers identified as needing phonological remediation according to the APP-R. Although t-tests indicated significant differences in some phonological process usage between the two subject groups, none of the children within the study were identified as needing phonological intervention. Thus, a chi-square comparison was not performed.

\section{DISCUSSION}

The lower SES, black preschoolers were expected to utilize community dialectical, black English speech patterns at the time of testing. In examining the significant differences between the white and black preschoolers in phonological process usage, it is clear that these 
TABLE IV

MEANS, STANDARD DEVIATIONS, AND I-VALUES FOR THE APP-R TEN PHONOLOGICAL PROCESSES FOR EACH GROUP OF SUBJECTS

\begin{tabular}{|c|c|c|c|c|c|c|}
\hline PROCESS & $\begin{array}{l}\text { BLAC } \\
\text { SUBII }\end{array}$ & CTS & $\begin{array}{l}\text { WHI } \\
\text { SUB }\end{array}$ & ETS & $\underline{t}$-VALUE & $\begin{array}{c}\text { SIGNIFICANCE } \\
\text { LEVEL }\end{array}$ \\
\hline & $x$ & $\mathrm{SD}$ & $x$ & $\mathrm{SD}$ & & \\
\hline $\begin{array}{l}\text { Syllable } \\
\text { Reduction }\end{array}$ & 2.06 & 3.34 & 0 & 0 & 2.3 & NS \\
\hline $\begin{array}{l}\text { Prevocalic } \\
\text { Singleton } \\
\text { Omission }\end{array}$ & .26 & .70 & .14 & .53 & .53 & NS \\
\hline $\begin{array}{l}\text { Post- } \\
\text { vocalic } \\
\text { Singleton } \\
\text { Omission }\end{array}$ & 3.40 & 4.37 & .21 & .80 & 2.68 & NS \\
\hline $\begin{array}{l}\text { Consonant } \\
\text { Sequence } \\
\text { Omission }\end{array}$ & 9.6 & 4.77 & 2.14 & 3.57 & 4.73 & .01 \\
\hline $\begin{array}{l}\text { Strident } \\
\text { Deficiency }\end{array}$ & 5.8 & 3.25 & 1.69 & 1.75 & 4.06 & .01 \\
\hline $\begin{array}{l}\text { Velar } \\
\text { Deficiency }\end{array}$ & 8.0 & 9.21 & 1.07 & 2.12 & 2.74 & .01 \\
\hline $\begin{array}{l}\text { Liquid /1/ } \\
\text { Deficiency }\end{array}$ & 3.60 & 6.63 & 7.14 & 17.95 & .71 & NS \\
\hline $\begin{array}{l}\text { Liquid /r/ } \\
\text { Deftciency }\end{array}$ & 3.6 & 5.28 & 3.07 & 6.04 & .25 & NS \\
\hline $\begin{array}{l}\text { Nasal } \\
\text { Deficiency }\end{array}$ & 1.06 & 3.03 & .35 & 1.33 & .80 & NS \\
\hline $\begin{array}{l}\text { Glide } \\
\text { Deficiency }\end{array}$ & 5.33 & 7.43 & 1.42 & 3.63 & 1.77 & NS \\
\hline
\end{tabular}

NS = not significant at .01 level 
preschoolers did use some characteristics of black English within their speech when uttering one-word responses to the APP-R. Specifically more frequently than their white counterparts, they used the patterns of consonant sequence omission and strident deficiency.

Socioeconomic status was controlled in this study because it may be a factor in phonological process usage. That was not demonstrated within this study. Since both groups were from lower SES, differences between the two groups seemingly are attributable primarily to dialectal differences.

A similar study was conducted in Florida utilizing black preschooler's performance on the APP-R (Fleming \& Hartman, 1989). Although the authors did not indicate if statistical differences existed between specific processes, they concluded

...while black English phonological rules do affect specific test items of the CAPP, the information provided by the test appears not to be negatively influenced by the black English dialect spoken by the children (p. 4).

In that respect, the results of this study coincides with the research in Florida in that children using black English characteristics in their speech were not penalized by the CAPD when assessing phonological process usage. With few exceptions, the black English preschoolers performed consistently as a group. In comparison with the literature, two of the three differences demonstrated by the 
black preschool group are appropriate for black English vernacular, specifically consonant sequence omissions and strident deficiency (Hixon et al., 1980). Conversely, the literature review did not indicate that velar deficiency is characteristic of black English speakers.

For this particular black English speaking sample, this clinician expected three particular phonological processes to be significantly different in usage from the white preschool group. Although the occurrence of any of the phonological processes tested by the APP-R would not be inappropriate for black English speakers, consonant sequence omission, liquid /l/ deviations, and liquid /r/ deviations were expected to be statistically different based upon a handout (LeMoine, 1992) acquired from the administration within the school district where testing was completed. This handout specified these three processes as being characteristics of black English.

of these three expected phonological processes, consonant sequence omission was the only one that was actually shown to be significantly different in comparison to usage by white preschoolers. One of the two other processes that occurred more frequently in the speech of black preschoolers, that is strident deviation, is viewed within the literature as characteristic of black English but was not expected by the researcher to be viewed as significantly different because of local expectations 
(LeMoine, 1992). The velar deficiency pattern was not predicted by national nor local black English standards. It is important to note here that black English speaking characteristics vary from community to community and that although this sample performed consistently as a group, these phonological differences can only be expected of this age group in Portland, Oregon. Performance of the white preschool group, in comparison to the literature, was age and developmentally appropriate as expected.

It should be noted that the spontaneous speech of the black children as they were escorted to the testing room by this researcher tended to contain many more black English speech characteristics than what was witnessed during formal testing. This same phenomenon was observed by Rella (1989) of an older black English speaking sample ( $\bar{x}$ age $=9$ years). The observed differences between spontaneous speech and single-word test response speech usage may be a form of code-switching. Perhaps the black children have already learned that formal testing situations require a different type of speech. Alternatively, the change may be attributed to hearing the child in connected speech (walking down the hall) verses a one-word context (APP-R procedure).

In this study, the researcher monitored the need subjects had for a direct or delayed model of the target word. With a few exceptions, subjects did not require a model for the target word. Providing a model did not seem 
to influence production. For example, either one particular word was modeled for almost all subjects, as with vase, or even when a model was provided, the subjects produced the word incorrectly in their own developmental pattern, as with screwdriver.

The most important finding clinically, within this research, is that none of the black English speaking preschoolers were identified as needing phonological intervention, although they used a significantly higher percentage of phonologoical processes than their white counterparts. The highest percentage of occurrence for any one process for any subject was $32 \%$, below the $40 \%$ criterion. Hence, while a statistical difference exists between the two groups in the percentage of occurrence of phonological processes, the subjects were not identified as needing phonological remediation nor would it be recommended that individual phonological patterns be targeted. 
CHAPTER V

\section{SUMMARY AND IMPLICATIONS}

\section{SUMMARY}

Normal phonological development is characterized by phonological processes in preschool children. These processes are sound error patterns, in relation to the adult target, that are expected within the speech of normally developing children. As children grow older, they "outgrow" these developmental errors. Within the black English dialect, speakers may use a combination of these processes and not be considered phonologically impaired within their linguistic community. The purpose of this study was to assess and compare phonological process usage in the speech of lower socioeconomic black and white preschoolers.

The APP-R in conjunction with the CAPD was administered to two groups of 15 children to determine if significant differences exist in the usage of phonological processes between the two groups. Group 1 was comprised of 15 black preschoolers from an inner-city preschool program. Group 2 was comprised of 15 white preschoolers from a Headstart program. All children were identified by their respective speech-language pathologist as having normally developing speech for their linguistic community. 
Data analysis revealed black preschoolers used phonological processes with a higher frequency than white preschoolers. The phonological process usage mean for the black preschoolers was $4.26 \%(S D=1.94)$ and the mean for the white preschoolers was $1.71 \%(S D=2.86)$. Three of the ten basic processes were determined to be significantly different between the two groups, including: consonant sequence omission, strident deviation, and velar deviation.

The results were further examined to determine if either group of preschoolers was identified as needing phonological remediation based on their performance on the APP-R. None of the subjects in either group was identified as needing phonological remediation.

In conclusion, results indicated black English speaking preschoolers did use significantly more phonological processes in their speech, however, the APP-R did not identify these children as needing phonological remediation. These results demonstrate the APP-R to be an appropriate assessment tool when evaluating the speech of this Portland black English speaking sample.

\section{IMPLICATIONS}

\section{$\underline{\text { Research }}$}

Numerous factors could be altered within the design of this study that may change the conclusions in future research. Other assessment tools may identify black English 
speakers as phonologically impaired because those tools may use different standards for what constitutes a phonological impairment. These different standards may tend to identify children as phonologically disordered; whereas, the APP-R did not.

Spontaneous speech of the subjects may contain more phonological differences than were recorded utilizing a one-word response format. This question stems from the black English subjects utilizing many characteristics of black English while informally talking with this researcher, but "code-switching" into a more standard English dialect when formal testing began. Perhaps the researcher being white had an impact on the subjects switching into a more standardized English dialect; this may not occur if the researcher were black.

Code-switching between black English and a more formal dialect similar to standard English is an asset for these subjects. Although they were young, these normally developing preschoolers inherently understood a more formal environment (the testing situation) verses the preschool classroom or their homes, that required a different dialect. Perhaps if this researcher had worked in the class prior to the research being completed, this familiarity would change the subject's choice to code-switch into a more formal dialect. Remaining within the full extent of their black English register, an assessment tool may penalize these 
subjects in relation to phonological process usage.

Outside of this research design, other research may determine what constitutes black English. How many phonological processes does a subject need to use to be perceived as a black English speaker? Without this information, it may be difficult to determine if speakers have deviant phonologies or simply follow the standards of their community.

It is also important to research the possible test results black English speaking, phonologically impaired children would yield. Although results from the APP-R did not identify any subjects as phonologically impaired, all subjects were developmentally normal. The APP-R may yield a higher phonological process percentage than is accurate if impaired subjects were assessed.

The results of this study cannot be generalized to other linguistic cultural groups or other parts of the country. Generalization is not appropriate, hence, further research in these areas with other populations or other geographic regions would be appropriate.

\section{clinical}

Based on the results of this study, the APP-R is deemed appropriate for use in the Portland, Oregon, metropolitan area with black English speaking preschoolers. Within the design of this study, it was demonstrated that by the age of 5 years, these subjects were capable of code-switching from 
black English vernacular and into a more formal standard English dialect, when it is appropriate to do so. If black English speaking subjects are identified as needing phonological remediation and/or do not demonstrate the ability or understanding of when to code-switch from black English, further assessment may be deemed necessary. Clinically, finding the $A P P-R$ to be an appropriate assessment tool and the code-switching abilities of the preschool population in this area are the valuable aspects of this research. The APP-R has now been shown to be appropriate for preschool black English speakers in at least two regions of the country, that is, oregon and Florida. 


\section{REFERENCES}

Adler, S. (1979). Poverty children and their language: Implications for teaching and treating. New York: Grune \& Stratton, Inc.

Arlt, P. B., \& Goodban, M. J. (1976). A comparative study of articulation acquisition as based on a study of 240 normals, aged three to six. Language, speech, and Hearing services in the schools, 7, 173-180.

ASHA (1990). Code of Ethics of the American SpeechLanguage-Hearing Association, revised version.

Creaghead, N. A., Newman, P. W., \& Secord, W. A. (1989). Assessment and remediation of articulatory and phonological disorders (2nd ed.) Columbus, $\mathrm{OH}$ : Merrill Publishing Company.

Dale, P. (1976). Language development structure and function New York: Holt, Rinehart, and Winston.

Dyson, A. T., \& Paden, E. P. (1983). Some phonological acquisition strategies used by two-year-olds. Journal of Childhood Communication Disorders, 7, 6-18.

Edwards, M. L., \& Shriberg, L. D. (1983). Phonology applications in communicative disorders. San Diego, CA: College Hill Press.

Ervin-Tripp S., (1966). Language Development. In L. Hoffman (Ed): Review of child development research, 2, Ann Arbor, MI: University of Michigan Press.

Ferguson. C., \& Farwell, C. (1975). Words and sounds in early language acquisition: English initial consonants in the first 50 words. Language, 51, 1-61.

Fleming, K. O., \& Hartman, J. H. (1989). Establishing cultural validity of the Computer Analysis of Phonological Processes. Florida Educational Research Council Research Bulletin, 22.

Fudala, J., \& Reynolds, D. (1961). Arizona articulation proficiency scale. Los Angeles, CA: Western Psychological Services. 
Goldman, L., \& Fristoe, D. (1969). Goldman-Fristoe test of articulation. Circle Pines, MN.: American Guidance Service, Inc..

Gordon-Brannan, M. (1992). Unpublished manuscript, Portland State University, Portland, OR.

Grunwell, P. (1987). Clinical phonology (2nd ed.). Baltimore, MD: Williams \& Wilkins.

Haelsig, P. C., \& Madison, C. L. (1986). A study of phonological processes exhibited by 3-, 4-, and 5-year-old children. Language, Speech, and Hearing services in the schools, 17, 107-114.

Hejna, R. (1963). Developmental articulation test. Ann Arbor, MI: Speech Materials.

Hixon, T., Shriberg, L., \& Saxman, J. (1980). Introduction to communication disorders. Englewood Cliffs, NJ.: Prentice-Hall, Inc.

Hodson, B. W. (1985) . Computer analysis of phonological processes. [computer program] - stonington, IL.: Phonocomp.

Hodson, B. W. (1986). Assessment of phonological processesrevised. Danville, IL: Interstate Printers \& Publishers, Inc.

Hodson, B. W. (1992). Computer analysis of phonological deviations. [computer program]. Stonington, IL.: PhonoComp.

Hodson, B. W., \& Paden, E. P. (1991). Targeting intelligible speech. Austin, TX: Pro-Ed.

Ingram, D. (1981). Procedures for the phonological analysis of children's language. Baltimore, MD: University Park Press.

Ingram, D. (1989). Phonological disability in children (2nd ed.) San Diego, CA: Singular Publishing Group, Inc.

Khan, L., Dyson, A., Edwards, M., Hodson, B., \& Preisser, D. (1985). Early phonological development. Miniseminar presented at American Speech-Language-Hearing Association annual convention, Washington, D. C. 
Khan, L., \& Lewis, N. (1986). Khan-Lewis Phonological Analysis. Circle Pines, MN: American Guidance Service.

LeMoine, N. (1992). Mainstream English mastery: Serving the needs of African American students. Language Development Program for African American Students, Los Angles: Unpublished.

McDonald, E. (1964). A deep test of articulation. Pittsburgh, PA: Stanwix House.

Neidecker, E. A. (1987). School programs in speech-language organization and management (2nd ed.) Englewood Cliffs, NJ: Prentice-Hall.

Pendergast, A., Dickey, S., Selmar J., \& Soder, A. (1965). Photo articulation test. Danville, II: Interstate Printers \& Publishers, Inc.

Poole, I. (1934). Genetic development of articulation of of consonant sounds in speech. Elementary English Review, 11, 159-161.

Prather, E. M., Hedrick, D. L., \& Kern, C. A. (1975). Articulation development in children aged two to four years. Journal of Speech and Hearing Disorders, 40 , 179-191.

Preisser, D. A., Hodson, B. W., \& Paden, E. P. (1988). Developmental phonology: 18-29 months. Journal of Speech and Hearing Disorders, 53, 125-130.

Rella, E. (1989). Masters Thesis, Speech and Hearing Sciences, Portland state University.

Sander, E. K. (1972) . When are speech sounds learned? Journal of Speech and Hearing Disorders, 37, 55-63.

Seymour, H. N., \& Seymour, C. M. (1981). Black English and standard American English contrasts in consonant development of four and five-year old children. Journal of Speech and Hearing Disorders, 46, 274-280.

Shames, G. H. \& Wiig, E. H. (1986). Human communication disorders (2nd ed.). Columbus: Charles E. Merrill Publishing Company.

Shriberg, L., \& Kwiatkowski, J. (1980). Natural process analysis: A procedure for phonological analysis of continuous speech samples. New York: John Wiley. 
Smit, A. B. (1986). Ages of speech sound acquisition: comparisons and critiques of several normative studies. Language, Speech, and Hearing Services in the Schools, $17,175-186$.

Smit, A. B., Hand, L., Freilinger, J. J., Bernthal, J. E., \& Bird, A. (1990). The Iowa articulation norms project and its Nebraska replication, Journal of Speech and Hearing Disorders, 55, 779-798.

Smitherman, G. (1977). Talkin and testifyin, language of black America. Boston, MA: Houghton Mifflin Company.

Stoel-Gammon, C., \& Dunn, C. (1985). Normal and disordered phonology in children. Baltimore, MD: University Park Press.

Templin, M. C. (1957). Certain language skills in children (Monograph Series No. 26). Minneapolis: University of Minnesota, The Institute of Child Welfare.

Templin, M., \& Darley, F. (1969). The Templin-Darley tests of articulation. Iowa City, IA: Bureau of Educational Research and Service, The University of Iowa. Weiner, F. (1979). Phonological process analysis. Baltimore, MD: University Park Press.

Weiss, C., Gordon M., \& Lillywhite, H. (1987). Clinical management of articulatory and phonologic disorders (2nd ed.) Baltimore, MD: Williams \& Wilkins.

Wellman, B. L., Case, I. M., Mengert, E. G., \& Bradbury, D. E. (1931). Speech sounds of young children. Iowa city, IA: University of Iowa Press. 
APPENDIX A

CONSENT FORM FOR SUBJECTS PARENTAL CONSENT 
Dear Parent,

My name is Sharon Elise Soliday and I am a graduate student in Speech and Hearing Sciences at Portland State University.

I am conducting a study of speech sound production of children who are between 4 years, 6 months and 5 years, 6 months of age. I would like permission for your child to be one of the speakers in the study.

If you permit your child to be included, I will screen your child's hearing, do a 3-minute check of his/her communication abilities, and check with the speech-language pathologist about your child's speech and language development. He or she will then name 50 toy-like objects as I write down how they produce the various sounds. I will also tape record your child so that I may listen to it at a later time. The screening and test will last approximately 30 minutes for your child. You are welcome to attend and observe the testing.

There is no physical risk to your child involved. All test results are available to you upon request. Although testing may not directly benefit you or your child, it will help speech-language pathologists in the future to evaluate accurately speech sounds of preschool children.

Testing will occur on-site where your child is enrolled at day school, during the regular school time. Your child will miss 30 minutes of his or her day school experience. Your child's name will not be used within the study and you may withdraw your child's participation at any time, for any reason. I will be supervised by Mary Gordon-Brannan, Program Director, Speech and Hearing services, at Portland state University. If you have any questions or concerns related to this research, please contact me or my supervisor at Portland State University, 725-3533.

Please check below and return this to me in the attached envelope. Thank you for your time and cooperation.

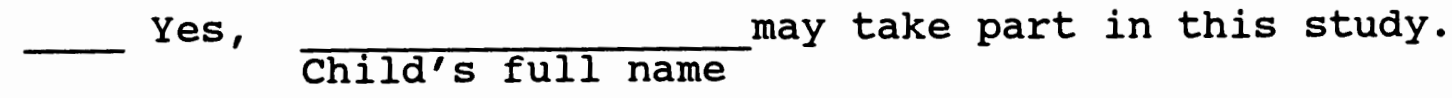

If participating, please complete the following information:

Mother: Occupation

Education level completed

(High School, 2 Yr. College, 4 Yr. College,

Advanced Degree) 
Father: Occupation

Education level completed

(High School, 2 Yr. College, 4 Yr. College, Advanced Degree)

No, I do not want my child to take part in this study.

signature of parent or

signature of witness

guardian

Date

Child's full name and date of birth

Address

Phone number

If you experience problems that are the result of your participation in this study, please contact the chair of the Human subjects Research Review Committee, Office of Grants and contracts, 105 Neuberger Hall, Portland state University, 503-725-3417. 
APPENDIX B

SLP CHECKLIST FOR SUBJECTS' NORMAL SPEECH DEVELOPMENT 
Dear Speech-Language Pathologist,

The parent(s) of permission for their child to participate within the phonological study. Please see the attached copy of the consent form.

Please indicate how you believe this child is performing within your teaching context.

Yes, this child has normally developing articulation skills relative to his or her own linguistic community for his/her age.

No, this child does not have normally developing articulation skills relative to his or her own linguistic community for his/her age.

Yes, this child's speech is intelligible relative to his or her own linguistic community for his/her age.

No, this child's speech is not intelligible relative to his or her own linguistic community for his/her age.

Please list other speech or language concerns you may have in consideration of his or her linguistic community.

Has this child's hearing been recently screened? If so, when?

Did he/she pass the hearing screening?

Site-based testing indicates this child's language skills are developmentaliy appropriate. YES NO

Thank you for taking the time to help with this research. If you have any questions or concerns feel free to call me at Portland state University, 725-3603. 
APPENDIX C

COMMUNICATION SCREEN PROTOCOL 


\title{
THE COMMUNICATION SCREEN
}

\author{
5-Year Screening Record Form \\ (use with ages 4 years 10 months -5 years 9 months)
}

CRITERION

1. Commands (only one repetition of one command allowed)

Completes 3 Objects: book, pen, two crayons

a. Get the book, bring it to the table and open it.

b. Give me the pen, open the book and stand up.

c. Take the book back, bring me the crayons and then close your eyes.

d. Clap your hands, stand up and then jump once.

2. Verbal imitation (no repetitions) Administer both parts $a$ and $b$.
a. Memory for related sentences
1. Jane had a dog.
2. The dog's name was Muffy.
3. The dog liked to play with Jane 's shoes.
4. Jane would hide her shoes for Muffy to find.

b. Memory for digits

$3-5$

$6-4-1$

$4-7-3-9$

$7-2-6-1$

3. Understands number concept of three. Objects: five blocks and five pencils.

a. Present five blocks and ask "Give me three."

b. Present five pencils and ask "Give me three."

c. Present four blocks and four pencils and say

"Give me two blocks and one pencil."

4. Definitions (record responses)

Completes 2

- a. What is a shoe?

b. What is a horse?

c. What is a pencil?

d. What is a cup?

e. What is a dress?

$f$ What is a stove?

What is a clock?

h. What is a doll?

i. What is a book? 
APPENDIX D

THE ASSESSMENT OF PHONOLOGICAL PROCESSES-REVISED 
THE ASSESSMENT OF PHONOLOGICAL PROCESSES - Revised

Barbara Willlams Hodson

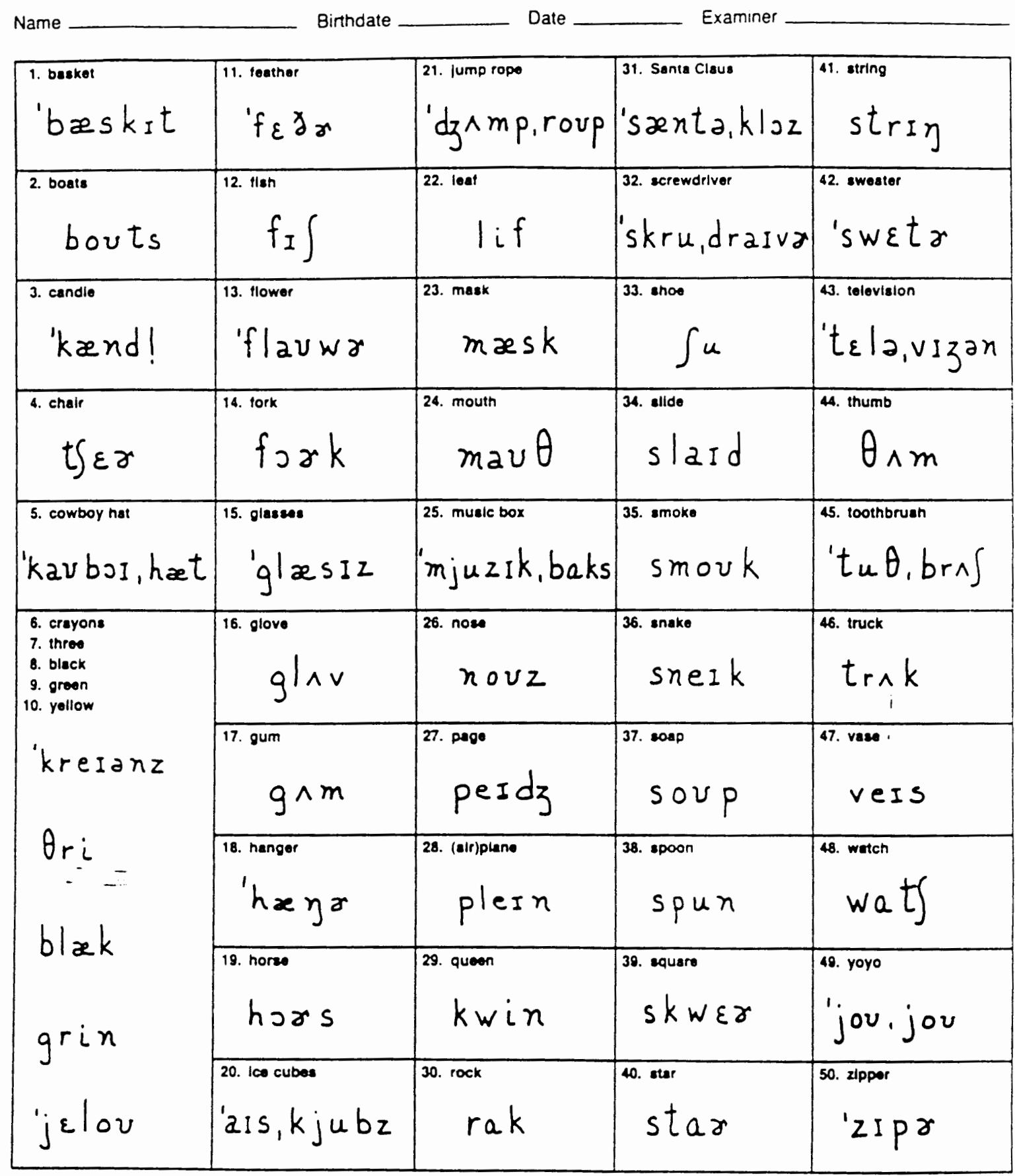


APPENDIX E

COMPUTER ANALYSIS OF PHONOLOGICAL PROCESSES 


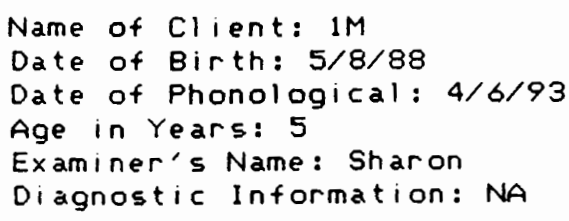

$\begin{array}{lc}\text { Phonological Analysis Summary } & \\ \text { Pattern Deviations } & \text { Percentage of } \\ \text { Occurrence } & \\ \text { Syllable Reduction } & 11 \\ \text { Prevocalic Singletons } & 2 \\ \text { Postuocalic Singletons } & 0 \\ \text { Consonant Sequences } & 8 \\ \text { Stridents } & 7 \\ \text { Velars } & 0 \\ \text { Liquid (1) } & 0 \\ \text { Liquid ( } r \text { ) } & 10 \\ \text { Nasals } & 0 \\ \text { Glides } & 0 \\ & \end{array}$

COMPUTER ANALYSIS OF PHONOLOGICAL PROCESSES Barbara Willi ams hodson Copyright 1985; PhonoComp 